\title{
Palynostratigraphy and depositional environment of Vastan Lignite Mine (Early Eocene), Gujarat, western India
}

\author{
M R RaO ${ }^{1, *}$, Ashok SAhni ${ }^{2}$, R S RAnA ${ }^{3}$ and Poonam Verma ${ }^{1}$ \\ ${ }^{1}$ Birbal Sahni Institute of Palaeobotany, 53 University Road, Lucknow 226 007, India. \\ ${ }^{2}$ CAS in Geology, Lucknow University, Lucknow 226 007, India. \\ ${ }^{3}$ Department of Geology, H.N.B Garhwal University, Srinagar 246 175, Uttarakhand, India. \\ *Corresponding author.e-mail: rao.mr2008@gmail.com
}

\begin{abstract}
Early Eocene sedimentary successions of south Asia, are marked by the development of extensive fossilbearing, lignite-rich sediments prior to the collision of India with Asia and provide data on contemporary equatorial faunal and vegetational assemblages. One such productive locality in western India is the Vastan Lignite Mine representing approximately a 54-52 Ma sequence dated by the presence of benthic zone marker species, Nummulites burdigalensis burdigalensis. The present study on Vastan Lignite Mine succession is based on the spore-pollen and dinoflagellate cyst assemblages and documents contemporary vegetational changes. 86 genera and 105 species belonging to algal remains (including dinoflagellate cysts), fungal remains, pteridophytic spores and angiospermous pollen grains have been recorded. On the basis of first appearance, acme and decline of palynotaxa, three cenozones have been recognized and broadly reflect changing palaeodepositional environments. These are in ascending stratigraphic order (i) Proxapertites Spp. Cenozone, (ii) Operculodinium centrocarpum Cenozone and (iii) Spinizonocolpites Spp. Cenozone. The basal sequence is lagoonal, palm-dominated and overlain by more open marine conditions with dinoflagellate cysts and at the top, mangrove elements are dominant. The succession has also provided a unique record of fish, lizards, snakes, and mammals.
\end{abstract}

\section{Introduction}

In recent years, Vastan Lignite Mine (latitude $21^{\circ} 25^{\prime} 47^{\prime \prime} \mathrm{N}$ and longitude $73^{\circ} 07^{\prime} 30^{\prime \prime} \mathrm{E}$ ) in Surat, Gujarat, western India (figure 1a), has attracted attention for its rich and diverse Early Eocene floral and faunal remains that occur in the beds of Cambay Shale Formation. A diversity of spore-pollen and dinoflagellate cysts (Mandal and Guleria 2006; Garg et al. 2008; Tripathi and Srivastava 2012), seeds and mangrove roots (Sahni et al. 2006), fossil wood (Guleria et al. 2009) and fossil fruits (Singh et al. 2010) have been recorded from Vastan
Lignite Mine succession. One of the most significant findings has been the occurrence of extensive Eocene rainforests dominated by the Dipterocarpaceae as evidenced by amber chemistry and wood anatomy (Rust et al. 2010). Recently Dutta et al. (2011a) reported the occurrence of Asian depterocarps from approximately $53 \mathrm{Ma}$ old sediments from western India based on fossil resin chemistry and palynological data. In addition to these, diverse herbivorous land mammals (Rana et al. 2005, 2008; Rose et al. 2009), insects preserved in amber (Alimohammadian et al. 2005; Rust et al. 2010); fossils of lower vertebrates (fish,

Keywords. Palynostratigraphy; palaeoecology and depositional environment; Early Eocene; Vastan Lignite Mine; Gujarat. 

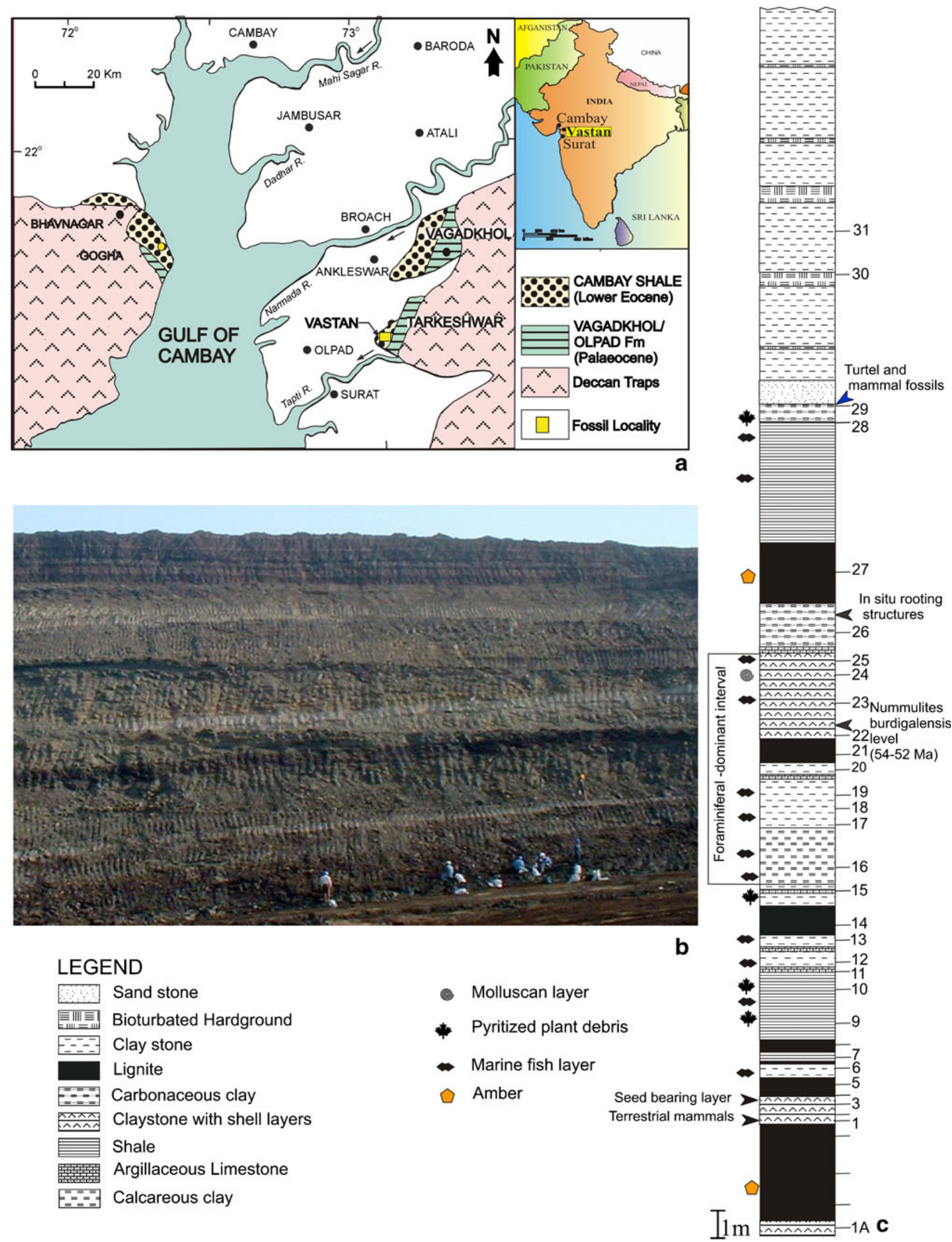

LEGEND

$\begin{array}{ll} & \text { Sand stone } \\ & \text { Cignite } \\ & \end{array}$

- Molluscan layer

* Pyritized plant debris

- Marine fish layer

$\checkmark$ Amber

b 
snakes, lizards and frogs) and invertebrates (mollusca, foraminifera and ostrocoda, Rana et al. 2004; Sahni et al. 2006) have also been documented.

The south Asian Palaeogene coal measures coincide with the appearance of a diverse and new vertebrate (predominantly mammalian) faunas marking the origin of several lineages that include whales, sirenians, lagomorphs, enigmatic anthracobunids, bats, artiodactyls and anthropoid primates (Bajpai et al. 2005a, b, c, 2006, 2007; Rana et al. 2004, 2005; Rose et al. 2006; Sahni et al. 2004, 2006; Kay et al. 2004; Smith et al. 2007). Many of the mammalian lineages have close similarity to comparable taxa known from coeval sections in Europe and North America (Rose et al. 2009). One of the challenges is, therefore to reconstruct vegetational histories and phytogeographic distribution for low latitude floras during this time based on peat accumalation along the passive western margin of India. With this objective, a systematic palynostratigraphic study was undertaken in the Vastan Lignite Mine section, north of Surat, Cambay Basin, Gujarat, western India.

The present study deals with the spore-pollen and dinoflagellate cyst assemblages obtained from different levels of Vastan Lignite Mine and associated sediments and the data generated has been utilized in erecting broad vegetational, palynostratigraphic and palaeoecological frame work.

Mandal and Guleria (2006) for the first time recorded a rich and diverse assemblage consisting of 71 genera and 82 species of algal and fungal spores, dinoflagellate cysts, pteridophytic spores and angiosperm pollen grains from Vastan Lignite Mine section of seam I and II. The assemblage is dominated by angiospermous pollen grains and scarcity of pteridophytic spores. They have erected one new genus Intectocolporites and four new species, viz., Verrutricolpites longicolpus, Yeguapollis indicus, Verrutricolporites cambayensis and Echitriletes communis of angiosperm affinity. Fungal remains are represented by hyphae, microthyraceous fruiting bodies and spores whereas algal forms are marked by Psiloschizosporis and Ovoidites. In addition to these, dinocyst (Operculodinium centrocarpum) and fresh water alga belonging to Botryococcus have also been recorded. More recently, Tripathi and Srivastava (2012) also reported pteridophytic spores (7 genera and 15 species), angiosperm pollen grains (19 genera and 34 species), fungal remains, dinoflagellate cysts (already published by Garg et al. 2008) and palynofacies studies from the same section. According to them, palynoflora is dominated by angiospermous pollen (48\%) whereas, pteridophytic spores (25\%) are sub-dominantly represented. Dinoflagellate cysts are more frequent in upper part of the sequence.
Based on the dispersed organic matter studies, they inferred that the lower and middle parts of the sequence were deposited under less anoxic conditions whereas in the upper part was deposited under the influence of completely anoxic condition.

\section{Global climatic events during Palaeocene-Eocene}

In the Early Eocene, the Indian plate was situated in an equatorial, high precipitation zone resulting in the formation of very thick peats preserved as lignites and coals in western and northeastern India. This was a time of several hyperthermal events (Gingerich 2006; Zachos et al. 2008; Clementz et al. 2010) which are believed to have triggered an active radiation of mammals and angiosperms including the spread of the first Shorea forests (Rust et al. 2010). During this period, Palm genera appeared, Caesalpinoidae diversified, the Durio (Bombacaceae) and Alangium became abundant, swamp forest developed and the entire continent was covered by multistoried rain forests (Morley 2000).

\section{Geology and stratigraphic framework}

The Cambay Basin consists of mainly faultbounded Palaeogene and Neogene subsurface sedimentary successions. The oldest sediments range in age from the Palaeocene to Lower Eocene and constitute the Vagadkhol/Olpad and Cambay Shale formations. The Cambay Shale is confined to the deeper part of the basin and grades into the Vagadkhol Formation eastwards near the basin margins abutting the Deccan trap. The Vagadkhol Formation consists of grey mottled clay stones, gritty and conglomeratic in places with leaves and petrified wood remains (Chandra and Chowdhary 1969; Sudhakar and Basu 1973). The succeeding units in the Gulf of Cambay range in age from Middle Eocene to lower part of Upper Eocene: the Anklesvar Formation consisting of fine to medium sandstones, siltstones, greenish grey and carbonaceous shale and rare coal; the Vasco Formation having a carbonaceous shale succession with rare silt and coal, and the Kalol Formation consisting of alternating grey shales, sandstones, siltstones, silty shale with coal bands (Sudhakar and Basu 1973; Bhandari et al. 1991).

The Vastan lignite open cast mine is operated by Gujarat Industrial Power Corporation for thermal power. The base of the mine exposes outcrops of the Cambay Shale. There are two mineable lignite seams, one at the top as Lignite- 1 and one at the mine floor referred to as Lignite-2. In addition, 
there are four to five thinner seams that are up to one meter or less thick (figure 1b, c).

\section{Material and methods}

Samples were collected systematically from different horizons of the Vastan Lignite Mine that mainly consists of carbonaceous clay, claystone, dark coloured shales with shell layers and lignites (figure 1c). In all, 33 samples were collected and processed for the recovery of palynofossils, of which 31 samples proved to be productive. The samples were treated with $\mathrm{HCL}, \mathrm{HF}$ and $\mathrm{HNO}_{3}$ followed by a treatment of $5 \% \mathrm{KOH}$. The slides were prepared in polyvinyl alcohol and mounted in Canada balsam. The slides have been deposited in the museum of Birbal Sahni Institute of Palaeobotany, Lucknow with repository numbers (13583 to 13640).

\section{Results and discussion}

\subsection{Taxonomic diversity of the Vastan Lignite Mine}

The recovered palynoassemblage from the Vastan Lignite Mine succession is rich and diversified. The total assemblage consists of 86 genera and 105 species belonging to algal remains ( 7 genera and 7 species, including dinoflagellate cysts), fungal remains ( 7 genera and 8 species), pteridophytic spores (15 genera and 17 species) and angiosperm pollen (57 genera and 73 species). Qualitatively and quantitatively, the assemblage is dominated by angiosperm pollen followed by pteridophytic spores. The palynomorphs recovered from Vastan Lignite Mine have affinities with 30 extant families and are referable to Botryococcaceae, Dinophyceae, Microthyriaceae, Melaconidiaceae, Dematiaceae, Polypodiaceae, Schizaeaceae, Lycopodiaceae, Cyatheaceae, Osmundaceae, Hymenophyllaceae, Liliaceae, Arecaceae, Bombacaceae, Dipterocarpaceae, Caesalpiniaceae, Polygalaceae, Gunneraceae, Euphorbiaceae, Rhizophoraceae, Lecythidaceae, Ctenolophonaceae, Proteaceae, Thymeliaceae, Droseraceae, Lythraceae, Alangiaceae, Lamiaceae, Plumbaginaceae and Oleaceae (Appendix 1). Of these, Arecaceae is the dominant family. Palms referable to the family Arecaceae (Palmae) are woody and arborescent monocotyledons, predominantly pantropical, and restricted to evergreen and semi-evergreen forests. Photomicrographs of well preserved and stratigraphically significant taxa have been shown in plates 1,2 and 3.

Pollen grains recovered from the lower part of the Vastan Lignite Mine Section (1A, 1 and 3 samples) have strong morphological affinities with the extant
Dipterocarpaceae pollen (plate 3(10)). The fossil pollen grains have been described under Dipterocarpuspollenites retilpilatus from the Miocene sediments of Kerala, south India (Kar 1992). The earliest fossil Dipterocarpus pollen so far recorded in SE Asia is from Oligocene (34-23 Ma) sediments of Borneo (Muller 1981). Here, we report an occurrence of Dipterocarpus pollen from approximately $53 \mathrm{Ma}$ old sediments from Vastan Lignite Mine, western India. Our findings are corroborated by the Rust et al. (2010) reported well preserved insects within the fossilized resins from Vastan mine section. They also assumed that the resins were produced by dipterocarps based on presence of resin canals within the wood. Recently Dutta et al. (2011b) recorded pollen resembling to modern Dipterocarpaceae from the shales of Eocene lignite of Matanomadh, Kutch Basin, western India.

\subsection{Quantitative analysis}

For quantitative analysis of the assemblage, 200 specimens per sample were counted. However, in cases where the yield was poor, only 150 palynomorphs were counted. Percentage frequencies of each palynotaxon or group of palynotaxa were calculated. Percentage frequencies of all palynotaxa were plotted under namely, very rare (below $2 \%$ ), rare $(3-10 \%)$, common (11-20\%), abundant (21-35\%) and predominant (above 35\%, figure 2). Percentage frequencies of all the palynomorphs have been critically studied and selected stratigraphically significant palynotaxa for making the biostratigraphic zonation. Three cenozones were recognized in the Vastan Lignite Mine on the basis of palynomorph frequencies. To establish and recognize these cenozones, parameters like the first appearance datum (FAD) and last appearance datum of (LAD) various palynotaxa, their maximum development, decline, restricted occurrence and absence have been taken in to consideration. Each cenozone has been formally instituted in accordance with the International Stratigraphic Guide (Hedberg 1976).

\subsection{Palynostratigraphic zonation}

The three cenozones established in Vastan Lignite Mine, Cambay Basin, Gujarat are given below in the ascending chronological order (figure 3).

(i) Proxapertites spp. Cenozone

(ii) Operculodinium centrocarpum Cenozone

(iii) Spinizonocolpites spp. Cenozone 

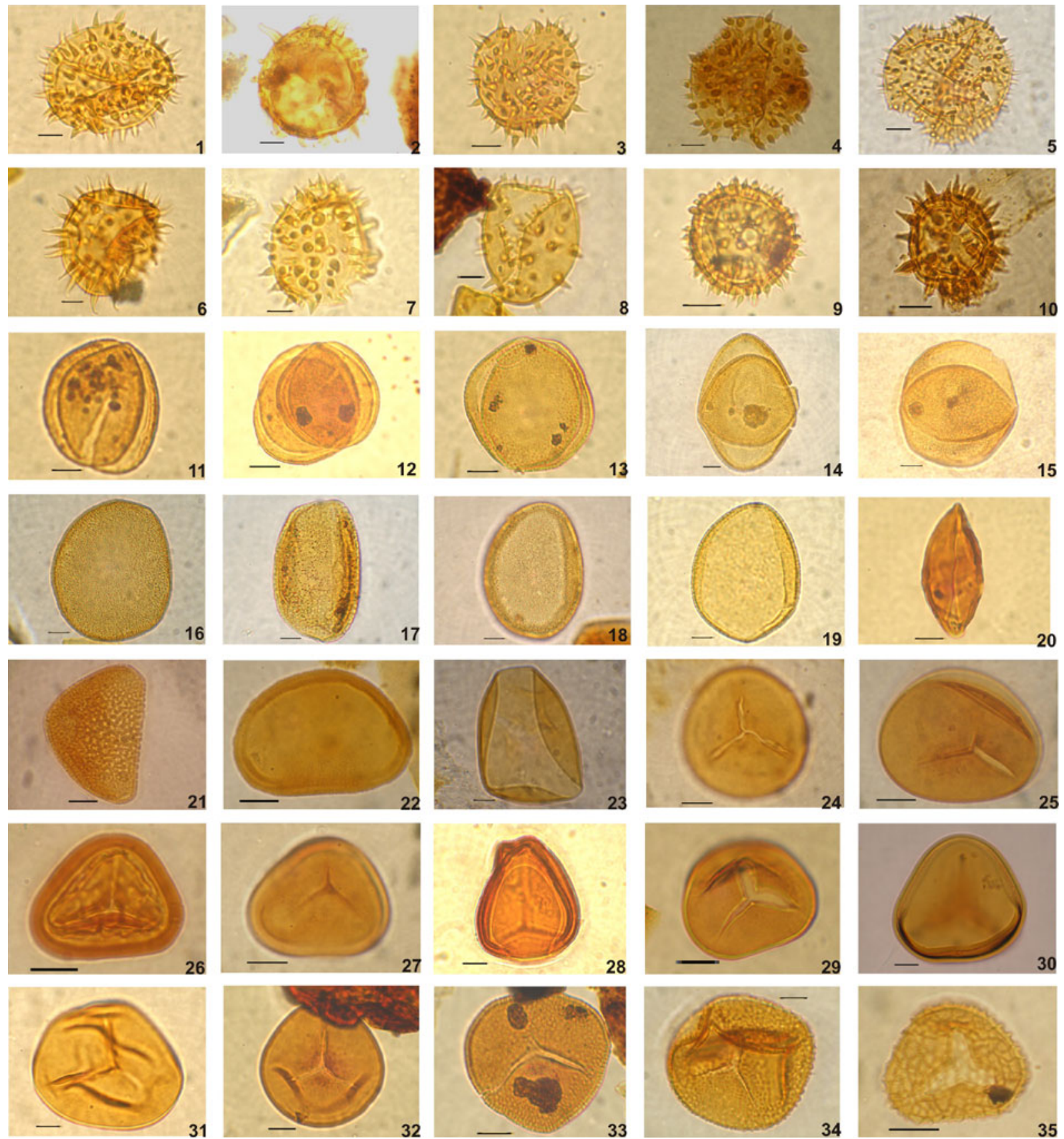

Plate 1. (1, 3) Neocouperipollis brevispinosus (Biswas) Venkatachala and Kar (1969), BSIP Slide Nos. 13583, T19; 13584, P27. (2) Spinizonocolpites baculatus, Muller (1968), BSIP Slide No. 13585, X38. (4, 5). Acanthotricolpites bulbospinosus Kar (1985), BSIP Slide Nos. 13586, T6; 13587, L28/3. (6-7) Neocouperipollis kutchensis (Venkatachala and Kar 1969) Kar and Kumar (1986), BSIP Slide No. 13588, W20/4; BSIP Slide No. 13589, G36/2. (8) Arengapollenites ovatus Kar and Bhattacharya (1992), BSIP Slide No. 13588, P10/2. (9) Spinizonocolpites adamantus Frederiksen (1994), BSIP Slide No. 13590, J16/4. (10) Neocouperipollis sp. BSIP Slide No. 13591, P8/4. (11, 12) Proxapertites assamicus (Sah and Dutta) Singh (1975), BSIP Slide Nos. 13584, W20/4; 13592, G28/4. (13) Proxapertites microreticulatus Jain et al. (1973), BSIP Slide No. 13593, U 25/4. (14-15) Proxapertites operculatus van der Hammen (1956), BSIP Slide Nos. 13586, K 28; 13594, Q 37/1. (16) Retimonocolpites ovatus (Sah and Kar), Kar (1985), BSIP Slide No. 13595, H 22/1. (17) Liliacidites microreticulatus Dutta and Sah (1970), BSIP Slide No. 13596, R 4/4. (18-19) Retimonocolpites ellipticus (Venkatachala and Kar) Kar (1985), BSIP Slide Nos. 13587, M 35/3; 13597, G 12. (20) Palmidites maximus Couper (1953), BSIP Slide No. 13584, H 6. (21) Longapertites sp. BSIP Slide No. 13598, K14/1. (22) Polypodiaceaesporites sp. BSIP Slide No. 13599, F 17/1. (23) Trichotomosulcites sp. BSIP Slide No. 13600, T 23/2. (24) Biretisporites sp. BSIP Slide No. 13601, N 29. (25, 27) Todisporites major Couper (1953), BSIP Slide Nos. 13602, H 29; 13603, M 29/4. (26) Pteridacidites sp. BSIP Slide No. 13604, S 18/4. (28) Intrapunctisporis intrapunctis Krutzsch (1959), BSIP Slide No. 13605, O31/4. (29, 31) Lygodiumsporites lakiensis Sah and Kar (1969), BSIP Slide Nos. 13606, L 8/4; 13583, B 31/4. (30) Lygodiumsporites eocaenicus Dutta and Sah (1970), BSIP Slide No. 13585, V 36. (32) Dandotiaspora telonata Sah et al. (1971), BSIP Slide No.13584, L 30/4. (33) Lycopodiumsporites parvireticulatus Sah and Dutta (1966), BSIP Slide No. 13593, J /13. (34) Osmundacidites cephalus Saxena (1978), BSIP Slide No. 13588, T 9/2. (35) Lycopodiumsporites sp. BSIP Slide No. 13599, M 14/4. Scale bar = $10 \mu \mathrm{m}$. 

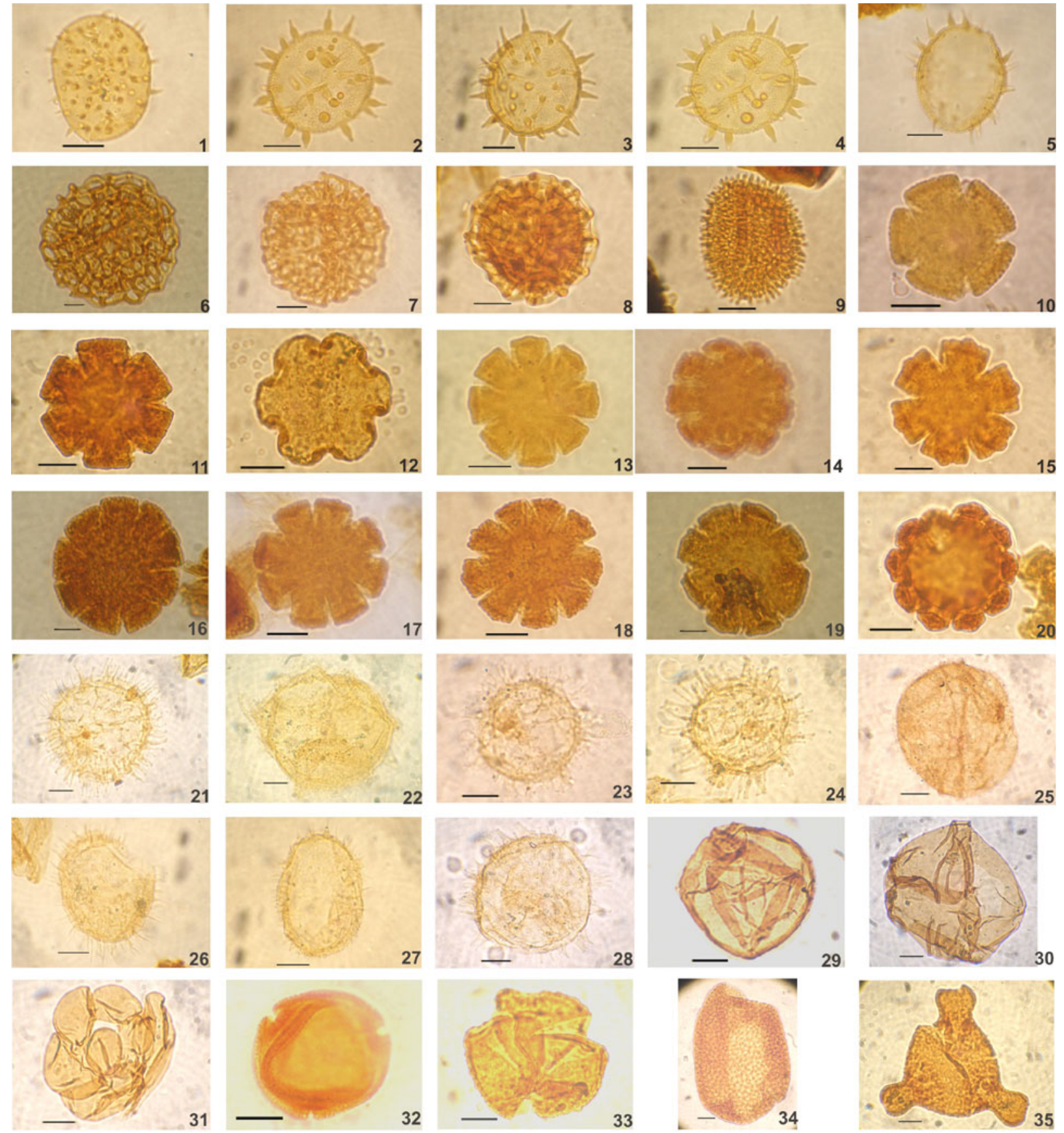

Plate 2. (1, 5) Spinomonosulcites achinatus (Sah and Kar) Singh and Misra (1991), BSIP Slide Nos. 13604, G 31; 13607, E 22. (2-4) Spinizonocolpites echinatus Muller (1968), BSIP Slide Nos. 13599 K8/2; 13599, J 16/1. (6-7) Retipollenites confuses Gonzalez-Guzman (1967), BSIP Slide Nos. 13595, K 27/2; 13604, M 33/1. (8) Ocimumpollenites indicus Kar (1996), BSIP Slide No. 13608, W 38/2. (9) Incrotonipollis neyvelii (Baksi et al.) Jansonius and Hills (1981), BSIP Slide No. 13604, K 10/1. (10) Polybrevicolporites nadhamunii Venkatachala and Kar (1969), BSIP Slide No. 13609 , V 35/2. (11) Retistephanocolpites kutchensis Saxena (1979), BSIP Slide No. 13610, G 6/4. (12) Pseudonathofagidites kutchensis Venkatachala and Kar (1969), BSIP Slide No. 13611, Q 25/3. (13, 16, 19) Retistephanocolpites flavatus (Sah and Kar) Saxena (1979), BSIP Slide Nos. 13599, E 13; 13588, N 16,13612, K 37/2. (14, 17-18) R. ornatus (Dutta and Sah) Saxena (1982), BSIP Slide Nos. 13613, G 30/3, 13614, G 35; 13613, Q 34/4. (15, 20) Ctenolpohonidites costatus HoekenKlinkenberg (1966), BSIP Slide No. 13615, O6; 13616, H5. (21, 24) Polysphaeridium subtile Davey and Williams (1966), emend. Bujak et al. (1980), BSIP Slide No. 13617, U 8/4; 13618, O30. (22) Kenleyia sp., BSIP Slide No. 13619, L 5/1. (23) Polysphaeridium sp., BSIP Slide No. 13619, K 18/4. (25) Heteraulacacysta granulata Jan Du Chene and Adediran (1985), BSIP Slide No. 13620, W 36/1. (26-27) Operculodinium centrocarpum (Deflandre and Cookson) Wall (1967), BSIP Slide No. 13621, M 11; 13622, V 8/2. (28) Spiniferites sp., BSIP Slide No. 13623, E 6. (29) Inaperturate pollen. BSIP Slide No. 13603, S 34. (30) Lejeunecysta hyalina (Geroch) Kjellstrom (1972), BSIP Slide No. 13591, U 27/2. (31) Foraminiferal lining BSIP Slide No. 13624, P 21/1. (32) Retitrescolpites robustus (Kar and Saxena) Kar (1985), BSIP Slide No. 13625, H 10/2. (33) Verrutricolpites sp., BSIP Slide No. 13620, H 10/2. (34) Matanomadhiasulcites maximus Saxena (1980), BSIP Slide No. 13626, O15/1. (35) Triangulorites bellus Kar (1985), BSIP Slide No. 13620, F 36. Scale bar $=10 \mu \mathrm{m}$. 

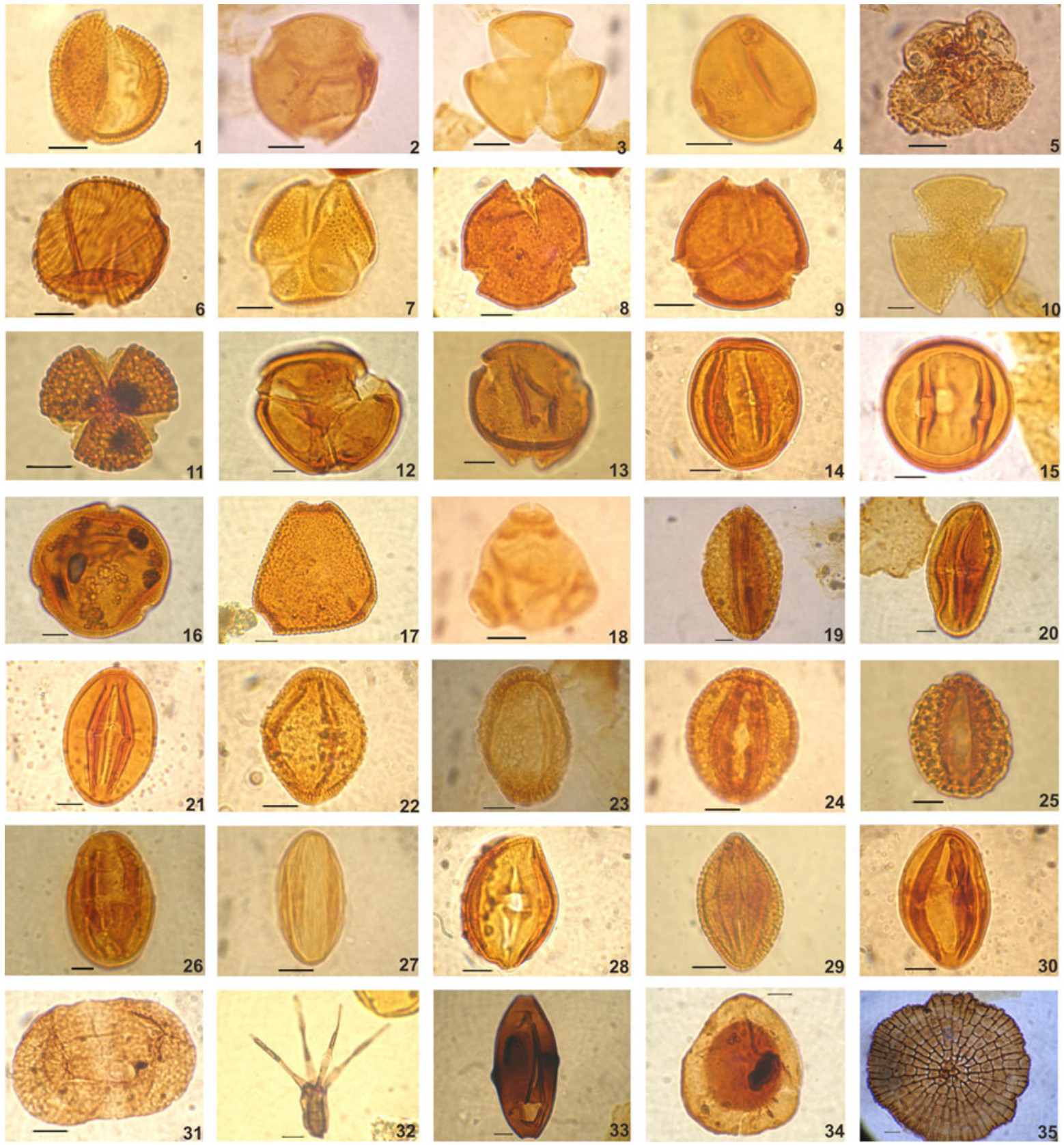

Plate 3. (1) Quilonipollenites sahnii Rao and Ramanujam (1978), BSIP Slide No. 13598, V 35. (2) Tricolporopollis sp., BSIP Slide No. 13627, H 40/4. (3) Tricolpate pollen, BSIP Slide No. 13599, J 31/4. (4) Triporopollenites parviannulatus Frederiksen (1994), BSIP Slide No. 13628, C 19. (5) Droseridites sp., BSIP Slide No. 13591, O31/4. (6) Striacolporites cephalus Sah and Kar (1970), BSIP Slide No. 13629, M 16/2. (7) Lanagiopollis rugularis Morley (1982), BSIP Slide No. 13630, G 33/2. (8) Dermatobrevicolporites dermatus Kar (1985), BSIP Slide No. 13630, T20. (9) Tribrevicolporites sp., BSIP Slide No. 13631, K 12/1. (10) Dipterocarpuspollenites retipilatus Kar (1992), BSIP Slide No. 13612, R 24/1. (11) Margocolporites tsukadii Ramanujam (1966), BSIP Slide No. 13632, V 5/3. (12, 13) Tribrevicolporites eocaenica Kar (1985), BSIP Slide No. 13586, G6; 13593, F 8/3. (14, 21) Rhoipites spp., BSIP Slide Nos. 13630, M 20; 13626, T 36/3. (15) Paleosantalaceaepites sp., BSIP Slide No. 13633, R10/3. (16) Dermatobrevicolporites exaltus Kar (1985), BSIP Slide No. 13598, S 32/1. (17) Proteacidites protrudes Sah and Kar (1970), BSIP Slide No. 13634, G 28/2. (18) Dorreenipites distinctus Navale and Misra (1979), BSIP Slide No. 13635, Q 22. (19) Retitrescolpites sp., BSIP Slide No. 13585, R 5/2. (20, 30) Rhoipites spp., BSIP Slide Nos. 13636, K 22; 13637, N 32/3. (22-23) Yeguapollis indicus Mandal and Guleria (2006), BSIP Slide Nos. 13610, N 12/3; 13599, T 36/2. (24) Barringtoniapollenites retipilatus Kar and Sharma (2001), BSIP Slide No. 13625, G 36/1. (25) Albertipollenites crassireticulatus (Dutta and Sah) Mandal and Rao (2001), BSIP Slide No. 13584, J 15/4. (26) Paleosantalaceaepites primitiva Biswas (1962), BSIP Slide No. 13634, D 20. (27) Striacolporites ovatus Sah and Kar (1970), BSIP Slide No. 13601, Q14. (28) Paleosantalaceaepites ellipticus Sah and Kar (1970), BSIP Slide No. 13638, V13. (29) Araliaceoipollenites descretus Venkatachala and Rawat (1973), BSIP Slide No. 13639 , N $10 / 4$. (31) Striatopodocarpites sp., BSIP Slide No. 13591, N 30/4. (32) Frasnacritetrus sp., BSIP Slide No. 13592 , U 25 /4. (33) Diporicellaesporites sp., BSIP Slide No. 13640, N 26. (34) Densipollenites sp., BSIP Slide No. 13595, R 21/4. (35) Phragmothyrites eocaenica Edwards emend. Kar and Saxena (1976). BSIP Slide No. 13540, M 14. Scale bar = $10 \mu \mathrm{m}$. 


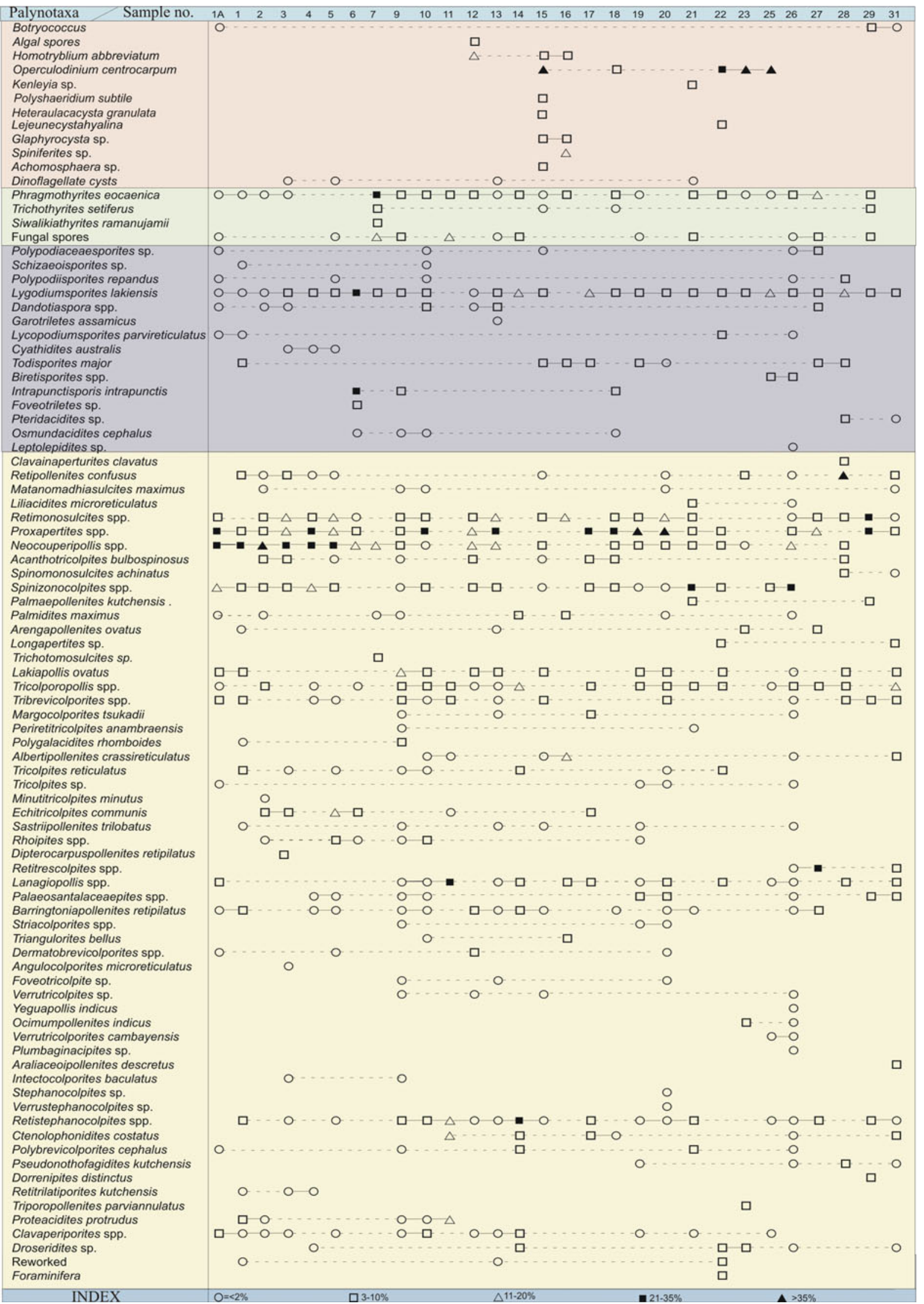

Figure 2. Percentage frequency of palynotaxa in Vastan Lignite, Gujarat. 


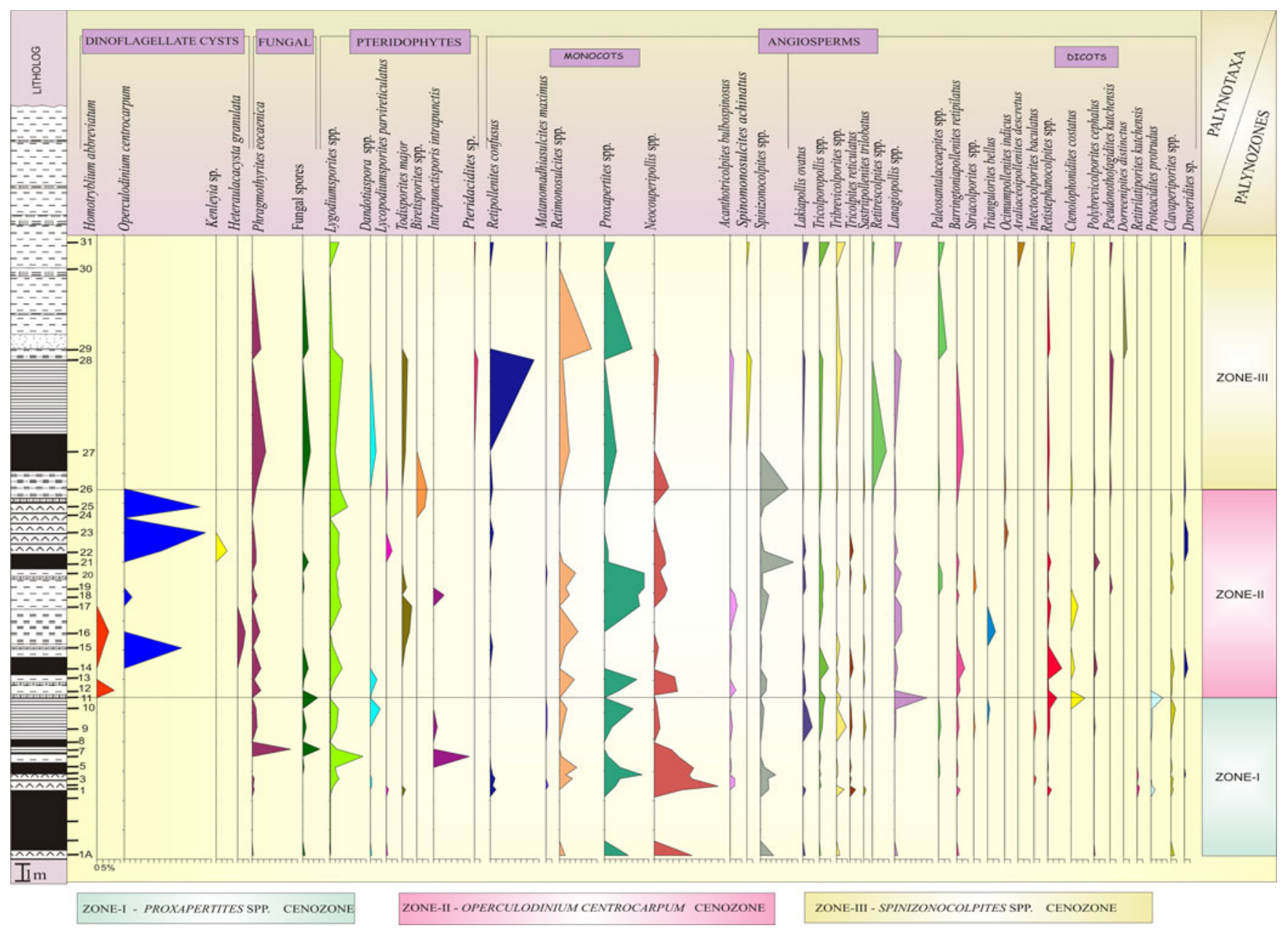

Figure 3. Palynostratigraphic zonation in Vastan Lignite, Gujarat.

\subsubsection{Proxapertites spp. Cenozone}

Type section: Lower part of the Vastan Lignite Mine exposed at $30 \mathrm{~km}$ northeast of Surat, Gujarat.

Lithology: This zone mainly consists of lignite alternating with claystone shell layers and shale. The thickness of the cenozone is approximately $7 \mathrm{~m}$.

Nature of contact: This cenozone constitutes the lowest biostratigraphic unit in the section and it is overlain by the Operculodinium centrocarpum Cenozone (sample nos. 1 to 11).

Species restricted to this cenozone: Intectocolporites baculatus and Retitrilatiporites kutchensis

Characteristic palynofossils: Phragmothyrites eocaenica, Lygodiumsporites spp., Intrapunctisporis intrapunctis, Proxapertites spp., Retimonosulcites spp., Neocouperipollis spp., Lakiapollis ovatus, Tribrevicolporites spp., Lanagiopollis spp., Tricolporopollis spp., Tricolpites reticulatus, Retistephanocolpites spp., Proteacidites protrudes and Clavaperiporites spp.

Remarks: The basal part of the succession exposed in Vastan Lignite Mine is a shell bed containing articulate shells, sometimes with well preserved valves lying side by side, suggesting quiet lagoonal conditions. Pyritized wood fragments and microvertebrate remains are abundant in these shell bed. During this study, a high diversity of lagoonal elements belonging to Arecaceae pollen (Neocouperipollis and Proxapertites) have been recorded, followed by mangrove elements (Spinizonocolpites, Barringtoniapollenites). In addition, terrestrial elements belonging to Bombacaceae (Lakiapollis, Tricolporopollis) and Alangiaceae (Lanagiopollis) are also recorded. An estuarine to lagoonal environment is inferred for the lower half of the mine section (Sahni et al. 2006). A thick 
band of lignite (Lignite-2) is underlain by the shell band and the samples from this horizon have not yielded any spore-pollen assemblages except some cuticles and trachieds of angiosperms. The lignite is overlain by claystone with shell layers. Arecaceous pollen is predominant in these clays, followed by the main terrestrial mammal dominant horizon. Dinoflagellate cysts represented by Polysphaeridium are also present, but their frequency is low. Garg et al. (2008) reported the presence of Muratodinium fimbriatum, Heteraulacacysta granulata and Operculodinium severinii at the base of the section.

The significant feature of this cenozone is the predominance of Arecaceous (monocots) pollen represented by Proxapertites, Neocouperipollis, Retimonosulcites and Acanthotricolpites. Of these, the frequency of Proxapertites spp. is dominant and constitutes the major part of the assemblage (up to $45 \%$ ), hence the cenozone is named after it. Other important genera belong to Bombacaceae (Lakiapollis ovatus, Tricolporopollis spp.). Thymeliaceae (Clavaperiporites spp.) and Gunneraceae (Tricolpites reticulatus) are also recorded.

The basal cenozone contains three lignite beds of varying thickness. The thickest of these several meters did not yield much pollen although it has yielded hundreds of seeds that can be clearly attributed to the family Oleaceae (Sahni et al. 2006). All three lignite seams contain fragmentary leaves, amber and an occasional carbonized wood fragment. The two upper lignite seams are thinner than the bottom seam and seem to have been deposited in wetter conditions as evidenced by the higher ratios of fungal remains and pteridophytic spores. The boundary between the basal and middle cenozone is marked by sample 11 which displays predominance of dicot pollen (particularly Lanagiopollis, Ctenolophonidites and Clavaperiporites) and the concomitant increase in the frequency of palm pollen suggesting the predominance of angiosperm-dominated forests.

Depositional environment of the cenozone: The pollen spectra of this cenozone indicate that lagoonal elements are dominant over the fresh water swamp forms followed by terrestrial elements. The frequency of dinoflagellate cysts $(2 \%)$ is less. However, this cenozone contains the main vertebrate producing layer that has diverse terrestrial mammals varying from large anthracobunids about a meter in length to small rodents with a large population of artiodactyls, primates, lagomorphs and tillodonts (Rose et al. 2009). These vertebrates appear to have been secondarily concentrated in small channels debouching into nearby lagoons.

\subsubsection{Operculodinium centrocarpum Cenozone}

Type section: Middle part of the Vastan Lignite Mine with a thickness of about $9.6 \mathrm{~m}$.

Lithology: The lithology mainly consists of shale, carbonaceous clay, calcareous clay and claystone with shell layers. In between the claystone and calcareous clay, two lignite bands are present.

Nature of contact: The upper part of the cenozone is carbonaceous clay overlain by the Spinizonocolpites spp. Cenozone (sample nos. 12 to 26).

Restricted palynofossils: Homotryblium abbreviatum, Operculodinium centrocarpum, Heteraulacacysta grannulata and Kenleyia sp., and the benthic foraminifer: Nummulites burdigalensis burdigalensis.

Characteristic palynofossils: Todisporites major, Neocouperipollis spp., Acanthotricolpites bulbospinosus, Spinizonocolpites spp., Tricolporopollis spp., Ocimumpollenites indicus, Retistephanocolpites spp., Ctenolophonidites costatus and Droseridites sp.

Remarks: In this cenozone, the dinoflagellate cysts increase in frequency in the lower part of the cenozone and become dominant at the top with the reappearance of lagoonal elements followed by terrestrial and mangrove forms. The frequency of dinoflagellate cysts increases markedly in this cenozone with an over $74 \%$ dominance over terrestrial palynomorphs in the molluscan shell layers that overlie the lignite band.

This cenozone is characterized by the dominance of dinoflagellate cysts (Homotryblium abbreviatum, Operculodinium centrocarpum, Heteraulacacysta grannulata and Kenleyia sp.). Of these, Operculodinium centrocarpum constitutes the major component (in sample no. 25, the percentage is $66 \%$ ) and therefore is of importance in differentiating this cenozone from overlying Spinizonocolpites spp. Cenozone. This cenozone includes the Nummulites burdigalensis burdigalensis level (SBZ 10) and the foraminifera dominant interval that mostly contains small benthic species (Sahni et al. 2006). This confirms the presence of a major transgressive event with the deepening of the basin.

Depositional environment of the cenozone: In this cenozone, dinoflagellate cysts are dominant throughout the middle part of the Vastan Lignite Mine and indicate a near shore to neritic bathymetry. The record of benthic foraminifera (Cibicidoides, Gavelinella, Prabullina, Bulimina, 
Fursenkonia, Cibicides and Storsella), and the presence of tests with large pores (Sahni et al. 2006) supports this view point.

\subsubsection{Spinizonocolpites spp. Cenozone}

Type section: Upper part of Vastan Lignite Mine with a thickness of about $11.6 \mathrm{~m}$.

Lithology: The lower part of the cenozone is made up of carbonaceous clay overlain by a lignite and followed by a silt-sized sandy level intercalated with multiple highly bioturbated hardground levels (sample nos. 27 to 31 ).

Restricted palynofossils: Pteridacidites sp., Spinomonosulcites achinatus, Araliaceoipollenites descretus, Retitrescolpites spp. and Dorrenipites distinctus.

Characteristic palynofossils: Phragmothyrites eocaenica, Lygodiumsporites spp., Retipollenites confuses, Retimonosulcites spp., Proxapertites spp., Paleosantalaceaepites spp., Spinizonocolpites spp. and Barringtoniapollenites retipilatus.

Remarks: This cenozone is characterized by the dominance of mangrove pollen belonging to Spinizonocolpites, Paleosantalaceaepites, Spinomonosulcites achinatus and Barringtoniapollenites. Of these, Spinizonocolpites spp. are dominant (28\%), hence the cenozone is named after it. The frequency of fresh water swamp and water edge elements (Lygodiumsporites, Lycopodiumsporites, Todisporites), lagoonal elements (Proxapertites, Neocouperipollis) and terrestrial elements (Lakiapollis, Retistephanocolpites and Ctenolophonidites costatus) is decreased whereas the percentage frequency of Retipollenites confuses increases (up to $45 \%)$.

Depositional environment of the cenozone: In this cenozone the frequency of mangrove elements (Spinizonocolpites, Spinomonosulictes, Paleosantalaceaepites and Barringtoniapollenites) has increased compared to the previous zones. Deposition took place in fluctuating water depths within extensive peat filled swamps, with embayments and lagoonal. Bioturbated hard grounds suggest poor rates of sediment infilling. This type of environment is also reported for coeval horizons such as the Kadi and Kalol Formations in the north of the Cambay Basin (Bhandari et al. 1991), and Tarakeswar Formation comprising Rajpardi Lignite (Samant and Phadtare 1997) and nearby
Bhavnagar Lignite (Samant 2000) and Surat Lignite deposits (Samant and Tapaswi 2001).

\subsection{Comparison with other Early Palaeogene palynological assemblages}

Spore-pollen assemblages from the extensive lignite-rich Palaeocene and Eocene successions of western India have been known for over 50 years. A significant palynoassemblage has been recorded from Early Eocene strata exposed in Rajpardi Lignite (Kar and Bhattacharya 1992; Kumar 1996; Samant and Phadtare 1997). Palynoflora recorded from these are diverse and represented by angiosperm pollen and pteridophytic spores and indicates diverse range of tropical rain forest elements (Samant and Phadtare 1997). The palynoflora reported from Early Eocene (Naredi Formation, Kutch, Gujarat) are also rich and varied with respect to the angiosperm pollen (Venkatachala and Kar 1969; Sah and Kar 1970; Kar 1978, 1985). In addition to these, palynomorphs have also been recorded from bore-hole-samples and open cast lignite mine succession of Barmer, Rajasthan (Tripathi et al. 2009; Tripathi and Srivastava 2010). However, most of these studies have focused more on the vegetational diversity of the floras and their palaeoecological interpretations. The present assemblage has been compared with all the known Early Eocene assemblages of India and it revelas that it is closely comparable to Rajpardi lignite and Naredi Formation (Kutch), Gujarat, India.

\section{Age of the Vastan Lignite deposit}

The age diagnostic benthic foraminifera Nummulites burdigalensis burdigalensis which is known from the upper part of the Vastan Mine sequence (figure 1c), indicates early Cuisan (ca. $53 \mathrm{Ma}$ ) age (Punekar and Saraswati 2010). Dinoflagellate cysts recorded in large numbers at specific levels, suggest according to Garg et al. (2008) an age "not older" than Thanetian and Sparnacian (ca 54$55 \mathrm{Ma}$ ). Clementz et al. (2010) reported second Eocene Thermal Maximum (ETM2; ca. 53.7 Ma) from the middle part of the Vastan Mine section based on strontium isotopes, stable carbon isotopes, microfossil biostratigraphy, and mammal fossils. Recently Dutta et al. (2011b) reported the occurrence of Asian depterocarps from approximately 53 Ma sediments from western India based on fossil resin chemistry and palynological data.

The palynoflora recorded from Early Eocene horizons of India (Kar 1985; Venkatachala et al. 1989; Samant and Phadtare 1997; Kar and Bhattacharya 1992; Kumar 1996; Mandal and Guleria 2006; 
Tripathi and Srivastava 2010, 2012) shows close resemblance to the present study.

Mandal and Guleria (2006) recorded a variety of spores-pollen from Vastan Lignite Mine section and the common genera between the two studies are: Cyathidites, Lygodiumsporites, Schizaeoisporites, Polypodiisporites, Liliacidites, Matanomadhiasulcites, Spinomonosulcites, Spinizonocolpites, Neocouperipollis, Acanthotricolpites, Proxapertites, Retitrilatiporites, Tricolpites, Lakiapollis, Margocolporites, Rhoipites, Minutitricolporites, Araliaceoipollenites, Paleosantalaceaepites, Lanagiopollis, Incrotonipollis, Striacolporites Clavaperiporites, Polygalacidites, Proteacidites, Yeguapollis, Retistephanocolpites, Ctenolophonidites, Pseudonathofagidites, Polybrevicolporites, Botryococcus and Operculodinium.

The genera recorded from the present study and absent in Mandal and Guleria (2006) are: Homotryblium, Polysphaeridium, Heteraulacacysta, Glaphyrocysta, Spiniferites, Achomosphaera, Lejeunecysta, Trichothyrites, Siwalikiathyrites, Meliola, Frasnacritetrus, Polypodiaceaesporites, Dandotiapsora telonata, Leptolepidites, Todisporites, Osmundacidites, Intrapunctisporis, Biretisporites, Pteridacidites, Clavainaperturites, Retimonosulcites, Retipollenites, Arengapollenites, Longapertites, Quilonipollenites, Dorrenipites, Margocolporites, Trichotamosulcites, Tribrevicolporites, Sastriipollenites, Foveotricolpites, Triangulorites, Dermatobrevicolporites, Periretitricolporites, Dipterocarpuspollentes, Barringtoniapollenites, Occimumpollenites, Plumbaginacipites, Polycolpites, Verrustephanocolpites and Triporopollenites (plates 1-3).

The occurrence of Dandotiaspora telonata, Retipollenites confuses, Retimonosulcites ovatus, Tricolpites reticulatus, Sastriipollenites trilobatus, Occimumpollenites indicus, Triangulorites bellus, Tricolporopollis spp. Dipterocarpuspollenites retipilatus, Dermatobrevicolporites dermatus and Periretitricolporites anambraensis in the present study are indicative of Early Eocene age for the Vastan Lignite Mine and not recorded by Mandal and Guleria (2006). On the basis of dinoflagellate cysts and palynological assemblage, Cambay Basin has also been assigned as Early Eocene (Mehrotra et al. 1996, 2002; Gupta et al. 1996) in age and corroborate our view.

\section{Palaeoecology and depositional environment}

For palaeoecological interpretations, the assemblage has been compared with modern plant and similarities found 30 families (Appendix 1).
Epiphyllous fungi mainly, represented by Microthyriaceae, are significant for indicating humidity. The fruiting bodies of these fossil fungi are abundant in the mesophytic forests of tropical to subtropical climate and for their development, heavy rainfall is essential (Dilcher 1965; Selkrik 1975). The records of fossil epiphyllous fungi such as Phragmothyrites, Trichothyrites and Siwalikiathyrites are good indicators of heavy precipitation during the deposition of the lignite. Pteridophytic spores are represented by the families of Osmundaceae (Osmundacidites, Todisporites), Schizaeaceae (Lygodiumsporites, Schizaeoisporites), Polypodiaceae (Polypodiaceaesporites, Polypodiisporites) and collectively indicate the prevalence of perennial water in their close vicinity, and warm and humid climate. Ferns such as members of the Cyatheaceae (Cyathidites), Lycopodiaceae (Lycopodiumsporites) and Pteridaceae (Pteris) are indicators of thick and tropical forest. The dominant population of the palynoflora is represented by 20 families of angiosperms. Of these, Arecaceae (Monocot) is the most abundant. Palms referable to the family Arecaceae are predominantly pantropical, and restricted to evergreen and semi-evergreen forests. The members of Arenga (Arengapollenites), Eugeissonia (Quilonipollenites) and Borassodendran (Retipollenites) together with other palm genera are good indicators of thick closed vegetation. The diversity of Spinizonocolpites (Nypa) complex in the present study appears to have been governed by the exploitation of various brackish water habitats and also by the presence of more effective competitors (Frederiksen 1994). The dominance and variety of palm pollen is sufficient for interpreting the climate as definite tropical. Pollen grains belonging to Bombacaceae (Lakiapollis ovatus and Tricolporopollis matanomadhensis) are also very abundant in this assemblage. Tropical rain forest elements belonging to the families Dipterocarpaceae (Dipterocarpuspollenites), Ctenolophonaceae (Ctenolophonidites, Retistephanocolpites) and Oleaceae (Retitrescolpites) also occur in the section. The overall assemblage indicates a warm and humid climate of a coastal zone, with a dense tropical rain forest in the vicinity of the site of deposition.

The palynoflora of Vastan Lignite Mine has been segregated into different ecological groups such as fungal, marine, terrestrial, fresh water swamp and water edge, mangrove and coastal elements (figure 4). An analysis of ecological groups represented by the Vastan Lignite Mine assemblages reveals that the coastal elements are dominant over fresh water swamp and terrestrial elements in the lower part of the section. The coastal elements (Palmidites, Palmaepollenites, 


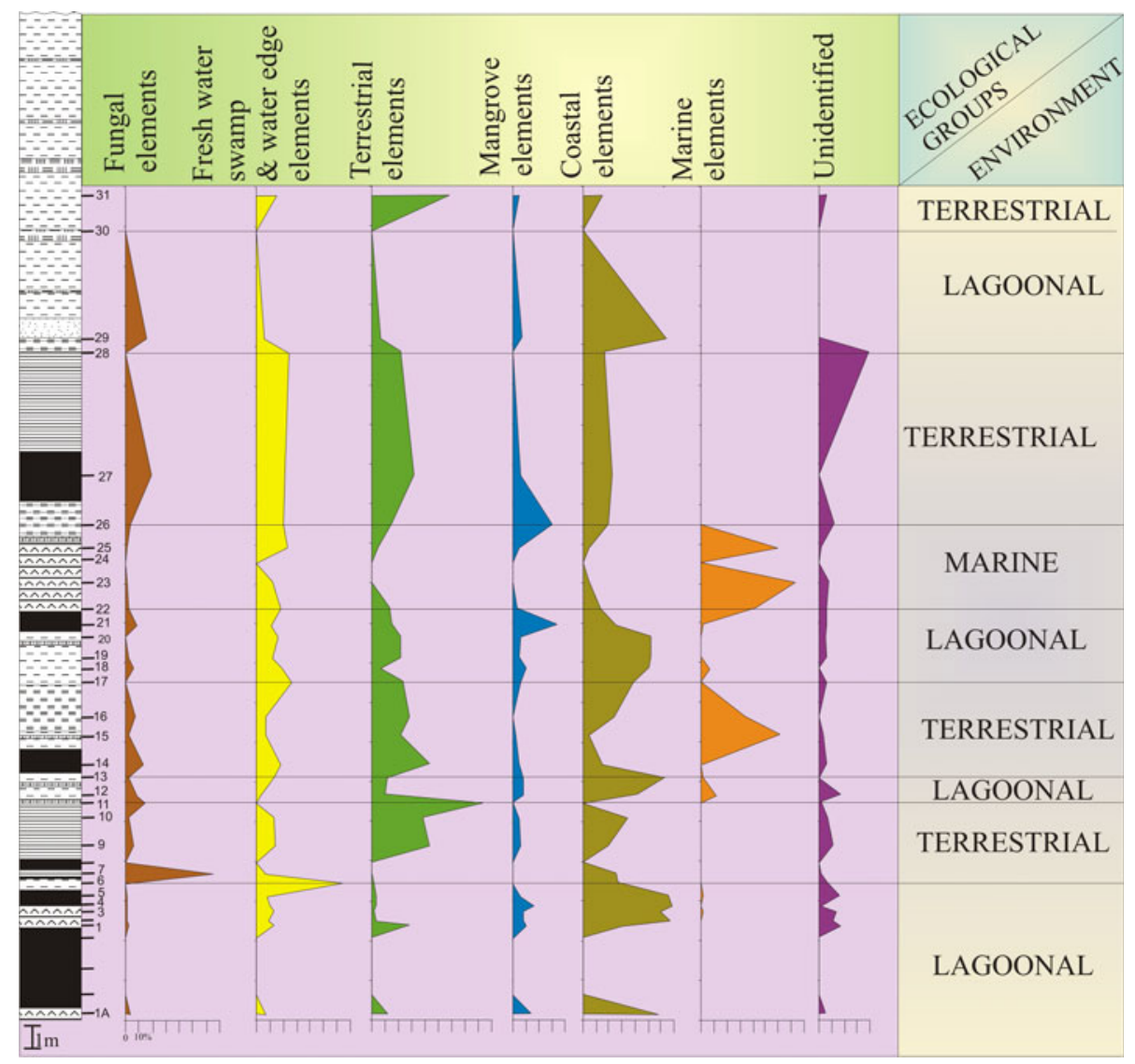

Figure 4. Representation of different ecological groups and their environment in Vastan Lignite, Gujarat.

Proxapertites and Neocouperipollis) are dominant throughout the section. The fresh water swamp and water edge elements are rare in the lower part and increase their frequency at the above lignite seam 2 and maintain their frequency (10-20\%) from the middle to top of the section. Terrestrial elements are co-dominant along with the coastal elements and shows appreciable frequency throughout the sequence. Mangrove elements (Spinizonocolpites, Paleosantalaceaepites, Spinomonosulcites and Barringtoniapollenites) are rare to dominant in the lower and middle parts of the section and predominant in the upper part. Marine elements are very rare in the lower part but increase their frequency in the middle part and dominate (Operculodinium centrocarpum) at the top of the middle upper part. However, they are absent above the lignite seam 1 (figure 4). The occurrence of Araliaceae (Araliaceoipollenites) and Proteaceae (Proteacidites) probably indicate the influence of wind-blown upland flora.

As discussed, the fungal remains consist of fruting bodies, hyphae and spores occur in plenty in organic matter rich Vastan sediments indicating activity of saprophytic fungi and these type of substrate occur in deltaic sediments (Traverse 1988). The occurrence of dinoflagellate cysts and mangrove taxa (Spinizonocolpites, Palaeosantalaceaepites and Barringtoniapollenites) indicate marginal marine conditions. Operculodinium centrocarpum suggests shallow depths in inner neritic zone and low salinity (Harland 1983; Morzadec-Kerfourn 1983). Kenleyia complex is most common in coastal and neritic environment (Crouch and Brinkhuis 2005). Benthic foraminifera, ostrocods and marine fish (gobiids) recorded from the shale horizon (Bajpai and Kapur 2004; Bhandari et al. 2005) also support the view of deeper marine environments for the middle part. This marine incursion probably reflects the early Eocene transgression in the Cambay Basin (Bhandari and Raju 1991). It is concluded that the deposition of the Vastan Lignite Mine succession took place in fluctuating conditions ranging through lacustrine, swamp, marshy and deltaic environments.

Figure 5 illustrates how sea level fluctuation can give rise to major environments of deposition observed at Vastan. There are basically four major elements, ranging from the marine (foraminifera, 


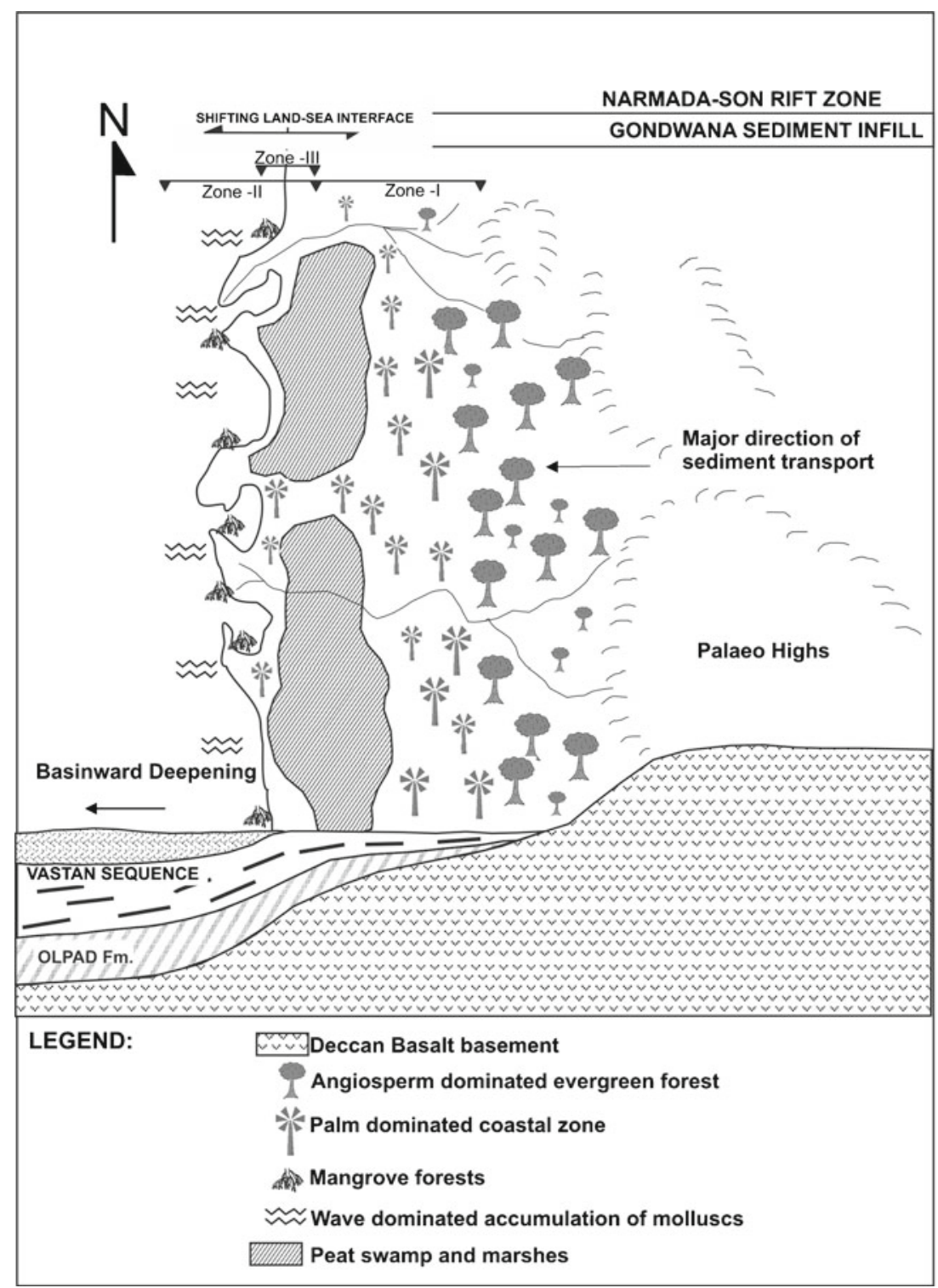

Figure 5. Schematic diagram of palaeovegetation zones along the passive margin of the Indian Plate during the Early Eocene.

dinoflagellate cyst-dominated), through coastal palm-dominated tracts, to deciduous and tropical rainforest components. Broadly, in a vertical succession, the Vastan sequence can be divided into three distinct depositional zones. The lower part (zone-I) mainly terrestrial fresh water as evidenced by algal elements including Botryococcus. The dominance of dinoflagellate cysts (Operculodinium, Homotryblium, Heteraulacacysta, Polysphaeridium, Kenleyia, Glaphyrocysta, Achomosphaera, Spiniferites and Leujenecysta hyalina) in the middle part (zone-II) and good representation of mangrove elements (Nypa, Rhizophora and Barringtonia) at the upper part of the section (zoneIII) indicate an estuarine environment with a marine incursion.

\section{Conclusions}

1. Palynological assemblage recorded from Vastan Lignite Mine consists of algal and fungal remains, dinoflagellate cysts, pteridophytic spores and angiosperm pollen grains. Qualitative and quantitative analyses reveal that angiosperm pollen register dominance over pteridophytic spores followed by dinoflagellate cysts.

2. The lower part of the Vastan Lignite Mine succession is dominated by the Arecaceous pollen (Neocouperipollis, Acanthotricolpites, Palmaepollenites, Arengapollenites, Proxapertites, Dorreenipites, Retipollenites and Quilonipollenites); middle part of the succession is dominated by dinoflagellate cysts 
(Operculodinium centrocarpum, Homotryblium abbreviatum, Polysphaeridium subtile, Heteraulacacysta grannulata, Kenleyia sp., Spiniferites sp. and Lejeunecysta hyalina) and the upper part of the succession is represented by mangrove pollen (Spinizonocolpites, Spinomonosulcites, Paleosantalaceaepites and Barringtoniapollenites).

3. On the basis of palynological data, the Vastan Lignite Mine succession is divisible in to three cenozones, viz., i) Proxapertites spp. Cenozone, ii) Operculodinium centrocarpum Cenozone and iii) Spinizonocolpites spp. Cenozone.

4. Deposition of the Vastan Lignite Mine succession took place in fluctuating conditions ranging through lacustrine, swampy, marshy and deltaic environments.

5. The studied succession has been assigned as Early Eocene in age by the presence of stratigraphically important marker taxa for the Early Eocene, i.e., Retipollenites confuses, Proxapertites spp., Neocouperipollis spp., Spinizonocolpites spp., Tricolpites reticulatus, Sastriipollenites trilobatus, Striacolporites spp., Triangulorites bellus, Tricolporopollis spp. and Retistephanocolpites spp. The occurrence of dinoflagellate cysts (Operculodinium centrocarpum, Homotryblium abbreviatum, Polysphaeridium subtile, Heteraulacacysta grannulata, Kenleyia sp.) also supports an Early Eocene age.

\section{Acknowledgements}

The authors appreciate the efforts of all the members of the National Geographic Society team who helped in the measurement of the section and collection of the samples. They are thankful to Dr N C Mehrotra, Director, Birbal Sahni Institute of Palaeobotany, Lucknow for providing facilities. The authors are also thankful to Dr Samir Sarkar, for his help in identifying the dinoflagellate cysts. They are also thankful to the anonymous reviewers for their critical comments and suggestions that improved the manuscript.

\section{Appendix 1}

\section{Algal remains}

Botryococcaceae: Botryococcus braunii

\section{Dinoflagellate cysts}

Dinophyceae: Operculodinium centrocarpum (Deflandre and Cookson) Wall (1967); Homotryblium abbreviatum Eaton (1976); Polysphaeridium subtile Davey and Williams (1966), Polysphaeridium sp., Heteraulacacysta granulate Jan Du Chene and Adediran (1985); Kenleyia sp.; Glaphyrocysta sp.; Spiniferites sp.; Achomosphaera sp.; Lejeunecysta hyalina (Geroch) Kjellstrom (1972).

\section{Fungal remains}

Microthyriaceae: Phragmothyrites eocaenica Edwards emend. Kar and Saxena (1976); Trichothyrites setiferus (Cookson) Saxena and Misra (1990); Siwalikiathyrites ramanujamii Saxena and Singh (1984).

\section{Fungal spores}

Melanconidiaceae: Meliola sp.

Dematiaceae: Frasnacritetrus sp.

\section{Pteridophytic spores}

Polypodiaceae: Polypodiaceaesporites sp.; Polypodiisporites repandus Takahashi (1964).

Schizaeaceae: Schizaeoisporites palanaensis Sah and Kar (1974); Lygodiumsporites lakiensis Sah and Kar (1969); L. eocaenicus Dutta and Sah (1970).

Lycopodiaceae: Lycopodiumsporites parvireticulatus Sah and Dutta (1966).

Matoniaceae: Dandotiasporites telonata Sah et al. (1971); D. plicata Sah et al. (1971); Garotriletes assamicus Singh and Singh (1978).

Cyatheaceae: Cyathidites australis Couper (1953).

Osmundaceae: Todisporites major Couper (1953); Intrapunctisporis intrapunctis Krutzsch (1959); Osmundacidites cephalus Saxena (1978).

Hymenophyllaceae: Biretisporites spp.

Pteridaceae: Pteridacidites sp.

\section{Angiosperm pollen grains}

Potamogetonaceae: Clavainaperturites clavatus van der Hammen and Wymstra (1964).

Liliaceae: Liliacidites microreticulatus Dutta and Sah (1970); Matanomadhiasulcites maximus (Saxena), Kar (1985); Retimonosulcites ovatus (Sah and Kar) Kar (1985); R. ellipticus (Venkatachala and Kar) Kar (1985).

Arecaceae: Retipollenites confuses GonzalezGuzman (1967); Proxapertites operculatus, van der Hammen (1956); P. assamicus (Sah and Dutta) Singh (1975); P. crassimurus (Sah and Dutta) Singh (1975); P. reticulatus (Kar and Saxena) Kar (1985); Neocouperipollis brevispinosus (Venkatachala and Kar) Kar and Kumar (1986); N. kutchensis 
(Venkatachala and Kar) Kar and Kumar (1986), Neocouperipollis sp.; Spinomonosulcites achinatus (Sah and Kar) Singh and Misra (1991); Acanthotricolpites kutchensis (Kar and Kumar) Singh and Misra (1991); Spinizonocolpites baculatus Muller (1968); S. echinatus Muller (1968); Palmidites major Couper (1953); Palmaepollenites kutchensis Venkatachala and Kar (1969); Arengapollenites ovatus Kar and Bhattacharya (1992); Longapertites sp., Quilonipollenites sahnii Rao and Ramanujam (1978); Retitrilatiporites kutchensis (Venkatachala and Kar) Singh et al. (1996) and Dorreenipites distinctus Navale and Misra (1979).

Bombacaceae: Lakiapollis ovatus Venkatachala and Kar (1969); Tricolporopollis matanomadhensis (Venkatachala and Kar) Tripathi and Singh (1985); T. decoris Dutta and Sah (1970).

Caesalpiniaceae: Margocolporites tsukadii Ramanujam (1966); Periretitricolpites anambraensis Jan Du Chene et al. (1978).

Polygalaceae: Polygalacidites rhomboides Kar and Bhattacharya (1992).

Gunneraceae: Tricolpites reticulates Cookson (1947).

Dipterocarpaceae: Dipterocarpuspollenites retipilatus Kar (1992).

Euphorbiaceae: Minutitricolpites minutus Kar (1985).

Anacardiaceae: Rhoipites pilatus, R. kutchensis Sah and Kar (1974).

Alangiaceae: Lanagiopollis tetracolporites Kumar (1996); L. ruguloverrucatus Morley (1982); L. rugularis Morley (1982).

Rhizophoraceae: Paleosantalaceaepites ellipticus; P. minutus Sah and Kar (1974).

Lecythidaceae: Barringtoniapollenites retipilatus Kar and Sharma (2001).

Lythraceae: Yeguapollis indicus Mandal and Guleria (2006).

Lamiaceae: Occimumpollenites indicus Kar (1996).

Plumbaginaceae: Plumbaginacipites sp.

Araliaceae: Araliaceoipollenites descretus Venkatachala and Rawat (1973).

Ctenolophonaceae: Ctenolophonidites costatus van Hoeken-Klinkenberg (1966), Retistephanocolpites kutchensis Saxena (1979), R. flavatus (Sah and Kar) Kar (1985), R. ornatus (Dutta and Sah) Saxena (1982).

Proteaceae: Proteacidites protrudes Sah and Kar (1970).

Thymeliaceae: Clavaperiporites jacobii Ramanujam (1966).

Droseraceae: Droseridites sp.

Unidentified: Inapertisporites kedvesii Elsik (1968), Inapertisporites sp.; Diporicellaesporites sp., Foveotriletes sp.; Leptolepidites sp.; Verrumonocolpites sp., Albertipollenites crassireticulatus
(Dutta and Sah) Mandal and Rao (2001); Trichotomosulcites sp.; Echitricolpites communis De Silva Pares Regali et al. (1974); Tribrevicolporites eocenicus Kar (1985), Tribrevicolporites sp., Tricolpites sp., Foveotricolpites sp.; Verrutricolpites sp., Sastriipollenites trilobatus Venkatachala and Kar (1969); Striacolporites striatus, S. ovatus Sah and Kar (1970); Triangulorites bellus Kar (1985); Dermatobrevicolporites dermatus (Sah and Kar) Kar (1985); D. exaltus Kar (1985); Angulocolporites microreticulatus Kar (1985); Verrutricolporites cambayensis Mandal and Guleria (2006); Intectocolporites baculatus Mandal and Guleria (2006); Verrustephanocolpites sp.; Polycolpites sp.; Polybrevicolporites cephalus Venkatachala and Kar (1969); Pseudonothofagidites kutchensis Venkatachala and Kar (1969) and Triporopollenites parviannulatus Frederiksen (1994).

\section{References}

Alimohammadian H, Sahni A, Patnaik R, Rana R S and Singh H 2005 First record of an exceptionally diverse and well preserved amber-embedded biota from Lower Eocene ( $52 \mathrm{Ma}$ ) lignites, Vastan, Gujarat; Curr. Sci. 89 1328-1330.

Bajpai S and Kapur V V 2004 Oldest known gobiids from Vastan Lignite Mine (Early Eocene), Surat District, Gujarat; Curr. Sci. 87 433-435.

Bajpai S, Kapur V V, Das D P, Tiwari B N, Sarvanan $\mathrm{N}$ and Sharma R 2005a Early Eocene land mammals from Vastan Lignite Mine, District Surat (Gujarat), western India; J. Palaeontol. Soc. India 50 101113.

Bajpai S, Kapur V V, Thewissen J G M, Tiwari B N and Das D P 2005b First fossil marsupials from India: Early Eocene Indodelphis n. gen and Jaegeria n. gen. from Vastan Lignite Mine, District Surat, Gujarat; J. Palaeontol. Soc. India 50 147-151.

Bajpai S, Kapur V V, Thewissen J G M, Tiwari B N, Das D P, Sharma R and Sarvanan N 2005c Early Eocene primates from Vastan Lignite Mine, Gujarat, western India; J. Palaeontol. Soc. India 50 43-54.

Bajpai S, Kapur V V, Thewissen J G M, Das D P, Tiwari B N, Sarvanan N and Sharma R 2006 New Early Eocene cambaythere (Perissodactyla, mammalian) from Vastan Lignite Mine, District Surat (Gujarat), India and an evaluation of cambaythere relationship; J. Palaeontol. Soc. India 51 101-110.

Bajpai S, Kapur V V, Das D P and Tiwari B N 2007 New Early Eocene Primates (Mammalia) from the Vastan Lignite Mine, District Surat (Gujarat), western India; J. Palaeontol. Soc. India 52 231-234.

Bhandari A and Raju D S N 1991 Tertiary sea level changes and transgression/regression cycles in Cambay, Kutch and Rajasthan basin. A review; In: Proceedings of the Conference on Integrated and Exploratory Research. Achievements and Perspectives (eds) Pandey J and Banerji V, Dehradun, pp. 169-177.

Bhandari A, Gupta P K and Juyal N P 1991 Integrated exploration research in Cambay Basin: Some aspects in Paleogene stratigraphy; In: Proceedings of the Conference on Integrated and Exploration Research, Achievements and Perspectives (eds) Pandey J and Banerji V, KDM 
Institute of Petroleum Exploration, Dehradun, pp. 159167.

Bhandari A, Singh H and Rana R S 2005 A note on occurrence of ostracodes from the Vastan Lignite Mine, Gujarat; J. Palaeontol. Soc. India 50 141-146.

Biswas B 1962 Stratigraphy of the Mahadeo, Langpar, Cherra and Tura Formations, Assam, India; Quart. J. Geo. Minn. Mettall. Soc. India 25 1-48.

Bujak J P, Downie C, Eaton G L and Williams G L 1980 Dinoflagellate cysts and acritarchs from the Eocene of Southern England; The Palaeontological Association, Special Papers on Palaeontology 24 1-100.

Chandra P K and Chowdhary L R 1969 Stratigraphy of the Cambay Basin; Bull. ONGC 6 37-50.

Clementz M, Bajpai S, Ravikant V, Thewissen J G M, Saravanan N, Singh I B and Prasad V 2010 Early Eocene warming events and the timing of terrestrial faunal exchange between India and Asia; Geology 39 15-18.

Cookson I C 1947 Fossil fungi from Tertiary deposits in the southern hemisphere; Proc. Linn. Soc. N.S.W. 72 207-214.

Couper R A 1953 Upper Mesozoic and Cainozoic spores and pollen grains from New Zealand; Bull. New Zealand Geol. Surv. Paleontology 22 1-77.

Crouch E and Brinkhuis H 2005 Environmental change across the Paleocene-Eocene transition from eastern New-Zealand: A marine palynological approach; Marine Micropaleontol. 56 138-160.

Davey R J and Williams G L 1966 The genus Hystrichosphaeridium and its aliies in Mesozoic and cainozoic dinoflagellate cysts; Bulletin British Museum (Natural History) Geology 3 1-24.

De Silva Pares Regali P M, Uesugui I and De Silva Santos A 1974 Palinologia dos sedimentos Meso-Cenozoicas do Brail (II); Boln. Tecn. Petrobras 17 263-301.

Dilcher D L 1965 Epiphyllous fungi from Eocene deposits in western Tennessee, USA; Palaeontographica 116 1-54.

Dutta S K and Sah S C D 1970 Palynostratigraphy of the Tertiary sedimentary formations of Assam: 5. Stratigraphy and palynology of South Shillong Plateau; Palaeontographica B131 1-72.

Dutta S, Tripathi S K M, Mallick M, Mathews R P, Greenwood, P F, Rao M R and Summons R E 2011a Eocene out-of-India dispersal of Asian dipterocarps; Rev. Palaeobot. Palynol. 166 63-68.

Dutta S, Mathews R P, Singh B D, Tripathi S K M, Singh A, Saraswati P K, Banerjee S and Mann U 2011b Petrology, palynology and organic geochemistry of Eocene lignite of Matanomadh, Kutch Basin, western India: Implications to depositional environment and hydrocarbon source potential; Int. J. Coal Geology $\mathbf{8 5}$ 90-102.

Eaton G L 1976 Dinoflagellate cysts from the Bracklesham beds (Eocene) of the Isle of Wight, Southern England; Bulletin British Museum (Natural History) Geology 26 227-332.

Elsik W C 1968 Palynology of a Paleocene Rockdale lignite, Milan county, Texas-1. Morphology and Taxonomy; Pollen Spores $10263-314$.

Frederiksen N O 1994 Middle and late Palaeocene angiosperm pollen from Pakistan; Palynology 18 91-137.

Garg R, Ateequzzaman K, Prasad V, Tripathi S K M, Singh I B, Jauhri A K and Bajpai S 2008 Age-diagnostic dinoflagellate cysts from the lignite-bearing sediments of the Vastan Lignite Mine, Surat District, Gujarat, western India; J. Palaeontol. Soc. India 53 99-105.

Gingerich P 2006 Environment and evolution through the Paleocene-Eocene thermal maximum; Trends in Ecology EG Evolution 21 246-253.
Gonzalez-Guzman A E 1967 A palynologic study on the Upper Los Cuervos and Mirador Formations (Lower and Middle Eocene), Tibú Area, Colombia; Leiden, E. J. Brill $68 \mathrm{p}$.

Guleria J S, Sahni A, Shukla A and Singh H A 2009 Teredolites, infested fossil wood from the lower Eocene sediments of Vastan Lignite Mine of Gujarat, western India; Palaeobotanist 58 93-99

Gupta A, Kotnala S K and Poovenan A 1996 Palynostratigraphy and palaeoenvironmental analysis of subsurface Paleogene sequence of Jambusar-Dabka area, south Cambay Basin; In: Contribution to XV Indian Colloquim on Micropalaeontology and Stratigraphy (eds) Pandy J, Azmi R J, Bhandari A and Dave A, KDM Institute of Petroleum Exploration and Wadia Institute of Himalayan Geology, Dehradun, pp. 615-633.

Harland R 1983 Distribution maps of recent dinpflagellate cysts in bottom sediments from the north Atlantic ocean and adjacent seas; Palaeontology 26 321-387.

Hedberg H D 1976 International Stratigraphic Guide - A Guide to Stratigraphic Classification, Terminology and Procedure (New York, NY: Wiley), pp. 1-200.

Hoeken-Klinkenberg P M J 1966 Maestrichtian, Paleocene and Eocene pollen and spores from Nigeria; Leidse Geology Meded. 38 37-48.

Jain K P, Kar R K and Sah S C D 1973 A palynological assemblage from Barmer, Rajasthan; Geophytology $\mathbf{3}$ $150-165$.

Jan Du Chene R E, Onyike M S and Sowunmi M A 1978 Some new Eocene pollen of the Ogwashi-Asaba Formation, south-eastern Nigeria; Revista Espanola De Micropaleontologica 10 285-322.

Jan Du Chene R E and Adediran S A 1985 Late Palaeocene to Early Eocene dinoflagellate from Nigeria; Cahiers De Micropaleontologie 3 1-38.

Jansonius J and Hills L V 1981 Genera file of fossil spores; Spec. Publ. Canada, Department of Geology, pp. 13287.

Kar R K 1978 Palynostratigraphy of the Naredi (Lower) and the Harudi (Middle Eocene) formations in the district of Kutch, India; Palaeobotanist 25 161-178.

Kar R K 1985 The fossil floras of Kachchh-IV. Tertiary palynostratigraphy; Palaeobotanist 34 1-280.

Kar R K 1992 Occurrence of Dipterocarpus type of pollen from the Miocene sediments of Kerala, south India; J. Palynol. 28 79-85.

Kar R K 1996 On the origin of Ocimum (Lamiaceae): A palynological approach; Palaeobotanist 43 45-50.

Kar R K and Bhattacharya M 1992 Palynology of Rajpardi lignite, Cambay Basin and Gujar Dam and Akri lignite, Kutch Basin; Palaeobotanist 39 250-263.

Kar R K and Kumar M 1986 Neocouperipollis - a new name for Couperipollis Venkatachala and Kar; Palaeobotanist 35 171-174.

Kar R K and Saxena R K 1976 Algal and fungal microfossils from Matanomadh Formation (Palaeocene), Kutch, India; Palaeobotanist 23 1-15.

Kar R K and Sharma P 2001 Palynostratigraphy of Late Palaeocene and Early Eocene sediments of Rajasthan, India; Palaeontographica B256 123-157.

Kay R F, Schmitt D, Vinyard C J, Perry J M G, Shigehara N, Takai M and Egi N 2004 The palaeobiology of Amphipithecidae, south Asian late Eocene primates; J. Hum. Evol. 46 3-25.

Kjellstrom 1972 Archaeopyle formation in the genus Lejeunia emend.; Geologiske Forningenes i Stockhlom forhand ungar 94 467-469.

Krutzsch W 1959 Einige neue Formgattungen und-Arten von Sporen und Pollen aus der Mitteleuropaischen 
Oberkreide und dem Tertiar; Palaeontographica $B \mathbf{1 0 5}$ 125-157.

Kumar M 1996 Palynostratigraphy and palaeoecology of Early Eocene palynofloral of Rajpardi lignite, Bharuch District, Gujarat; Palaeobotanist 43 110-121.

Mandal J and Guleria J S 2006 Palynology of Vastan Lignite (Surat District), Gujarat, its age, palaeoecology and depositional environment; Palaeobotanist $\mathbf{5 5}$ 51-66.

Mandal J and Rao M R 2001 Taxonomic revision of tricolpate pollen from Indian Tertiary; Palaebotanist $\mathbf{5 0}$ 341-352.

Mehrotra N C, Nautiyal D D and Berry C M 1996 Dinocyst biostratigraphy of palynozones of the Gulf of Cambay; In: Contribution to XV Indian Colloquim on Micropalaeontology and Stratigraphy (eds) Pandy J, Azmi R J, Bhandari A and Dave A, KDM Institute of Petroleum Exploration and Wadia Institute of Himalayan Geology, Dehradun, pp. 683-694.

Mehrotra N C, Venkatachala B S, Swamy S N and Kapoor P N 2002 Palynology in Hydrocarbon Exploration - The Indian Scenario. Part-I; Category-I, Basins; Geol. Soc. India Memoir 48 1-162.

Morley R J 1982 Fossil pollen attributed to Alangium Lamarck (Alangiaceae) from the Tertiary of Malaysia; Rev. Palaeobot. Palynol. 36 65-94.

Morley R J 2000 Origin and Evolution of Tropical Rain Forests; John Wiley \& Sons, Ltd., pp. 1-339.

Morzadec-Kerfourn M T 1983 In teret des kystes de dinoflagelles pour 1' establissement de reconstitution Paleogeographique: example du Golfe de Gabes (Tunisie); Cahiers de Micropaleontologie 4 15-22.

Muller J 1968 Palynology of the Pedawan and Plateau Sandstone formations (Cretaceous-Eocene) in Sarawak, Malaysia; Micropaleontology 14 1-37.

Muller J 1981 Fossil pollen records of extant angiosperms; Bot. Rev. 47 1-142.

Navale G K B and Misra B K 1979 Some new pollen grains from Neyveli lignite, Tamil Nadu, India; Geophytology $\mathbf{8}$ 226-239.

Punekar J and Saraswati P K 2010 Age of the Vastan lignite in context of some oldest Cenozoic fossil mammals from India; J. Geol. Soc. India $\mathbf{7 6} 63-68$.

Ramanujam C G K 1966 Palynology of the Miocene lignite from South Arcot District, Madras, India; Pollen. Spores 8 149-203.

Rana R S, Kumar K and Singh H 2004 Vertebrate fauna from the subsurface Cambay Shale (Lower Eocene), Vastan Lignite, Gujarat India; Curr. Sci. 87 1726-1733.

Rana R S, Singh H, Sahni A, Rose K D and Saraswati P K 2005 Early Eocene chiropterans from a new mammalian assemblage (Vastan Lignite Mine, Gujarat, western peninsular margin): Oldest known bats from Asia; J. Palaeontol. Soc. India 50 93-100.

Rana R S, Kumar K, Escarguel G, Sahni A, Rose K D, Smith H and Singh L 2008 An ailuravine rodent from the lower Eocene Cambay Formation at Vastan, western India, and its palaeobiogeographic implications; Acta Palaeontological Polonica 53 1-14.

Rao K P and Ramanujam C G K 1978 Palynology of the Neogene Quilon beds of Kerala state in south India. 1. Spores of pteridophytes and pollen of monocotyledons; Palaeobotanist 30 68-100.

Rose K D, Rana R S, Sahni A, Kumar K, Missiaen P, Singh L and Smith T 2009 Early Eocene Primates from Gujarat, India; J. Hum. Evol. 56 329-438.

Rose K D, Smith T, Rana R S, Sahni A, Singh H, Miassiaen P and Folie A 2006 Early Eocene (Ypresian) continental vertebrate assemblage from India, with description of a new Anthracobunid (Mammalia, Tethytheria); J. Verte. Paleontol. 26 219-225.

Rust J, Singh H, Rana R S, McCann T, Singh U, Anderson K, Sarkar N, Nascimbene P C, Stebner F, Thomas J C, Kraemer M S, Williams C J, Engel M S, Sahni A and Grimaldi D 2010 Biogeographic and evolutionary implications of a diverse paleobiota in amber from the early Eocene of India; Proc. Nat. Acad. Sci. USA 107 $18,360-18,365$.

Sah S C D and Dutta S K 1966 Palynostratigraphy of the sedimentary formations of Assam-1. Stratigraphical position of the Cherra Formation; Palaeobotanist 15 72-86.

Sah S C D and Kar R K 1969 Pteridophytic spores from the Laki Series of Kutch, Gujarat, India; J. Sen. Mem. Vol. Calcutta, pp. 109-112.

Sah S C D and Kar R K 1970 Palynology of the Laki sediments in Kutch-3. Pollen from the bore-holes around Jhulrai, Baranda and Panandhro; Palaeobotanist 18 $127-142$.

Sah S C D and Kar R K 1974 Palynology of the Tertiary sediments of Palana, Rajasthan; Palaeobotanist 21 $163-188$.

Sah S C D, Kar R K and Singh Y 1971 Stratigraphic range of Dandotiaspora Gen.nov. in the Lower Eocene sediments of India; Geophytology 1 54-63.

Sahni A, Rana R S, Loyal R S, Saraswati P K, Mathur S K, Rose K D, Tripathi S K M and Garg R 2004 Western margin Palaeocene-Lower Eocene lignites: Biostratigraphic and palaeoecological constraints; Pro. 2nd Conf. Asso. Petro. Geol. ONGC, pp. 1-22.

Sahni A, Saraswati P K, Rana R S, Kumar K, Singh H, Alimohammadin H, Sahni A, Rose K D, Singh L and Smith T 2006 Temporal constraints and depositional palaeoenvironments of the Vastan Lignite Sequence, Gujarat: Analogy for the Cambay shale hydrocarbon source rock; Indian J. Petrol. Geol. 15 1-20.

Samant B 2000 Palynostratigraphy and age of the Bhavnagar lignite, Gujarat, India; Palaeobotanist 49(1) 101-118.

Samant B and Phadtare N R 1997 Stratigraphic palynoflora of the Early Eocene Rajpardi lignite, Gujarat and the lower age limit of the Tarkeswar Formation of South Cambay Basin, India; Palaeontographica B245 1-108.

Samant B and Tapaswi P M 2001 Palynology of the Surat lignite (Early Eocene) deposits of Gujarat; J. Palaeont. Soc. 46 121-132.

Saxena R K 1978 Palynology of the Matanomadh Formation in type area, north-western Kutch, India (Part-1). Systematic description of pteridophytic spores; Palaeobotanist 25 448-456.

Saxena R K 1979 Palynology of the Matanomadh Formation in type area, northwestern Kutch, India (Part-2). Systematic description of gymnospermous and angiospermous pollen grains; Palaeobotanist 26 130-143.

Saxena R K 1980 Palynology of Matanomadh Formation in type area, north-western Kutch, India (Part-3). Discussion; Palaeobotanist 26 279-296.

Saxena R K 1982 Taxonomic study of the polycolpate pollen grains from the Indian Tertiary sediments with special reference to nomenclature; Rev. Palaeobot. Palynol. 37 $283-315$.

Saxena R K and Misra N K 1990 Palynological investigation of the Ratnagiri Beds if Sindhu Durg District, Maharashtra; Palaeobotanist 38 263-276.

Saxena R K and Singh H P 1984 Palynology of the Pinjor Formation (Upper Siwalik) exposed near Chandigarh, India; Palaeobotanist 30 325-339.

Selkrik D R 1975 Tertiary fossil fungi from Kiandra, New South Wales; Proc. Linn. Soc. New South Wales 100 70-94. 
Singh R Y 1975 Morphological study of the Retialites complex from Indian Tertiaries; Geophytology 5 89-104.

Singh A and Misra B K 1991 A new spinose monosulcate genus Spinomonosulcites and emendation of spinose porate Acanthotricolpites; Rev. Palaeobot. Palynol. 67 $217-227$.

Singh R Y and Singh H P 1978 Morphological observations on some spores and pollen grains from the Palaeocene subsurface assemblages of Garo Hills, Meghalaya; Palaeobotanist 25 475-480.

Singh A, Misra B K and Ramanujam C G K 1996 Trilatiporate pollen from Indian Palaeogene and Neogene sequences: Evolution, migration and continental drift; Rev. Palaeobot. Palynol. 91 331-352.

Singh H, Prasad M, Kumar K, Rana R S and Singh S K 2010 Fossil fruits from Early Eocene Vastan Lignite, Gujarat, India: Taphonomic and phytogeographic implications; Curr. Sci. 98 1625-1632.

Smith T, Rana R S, Missiaen P, Rose K D, Sahni A, Singh U and Singh L 2007 High bat (Chiroptera) diversity in the Early Eocene of India; Naturwissenchaften 99 1003-1009.

Sudhakar R and Basu D N 1973 A reappraisal of the Palaeogene stratigraphy of southern Cambay Basin; Bull. $O N G C 10$ 55-76.

Takahashi K 1964 Sporen und pollen der oberkretazeischen hakobouchi-Schichtengruppe, Hokkaido; Mem. Facul. Sci. Kyushu University Series 14 159-271.

Traverse A 1988 Palaeopalynology UNWINHYMAN, Boston, pp. 1-600.

Tripathi S K M and Singh H P 1985 Palynology of the Jaintia Group (Palaeocene-Eocene) exposed along JowaiSonapur Road, Meghalaya, India. Part-I. Systematic palynology; Geophytology 15 164-187.

Tripathi S K M and Srivastava D 2010 Palynological investigation, facies analysis and palaeoenvironmental interpretations from Late Palaeocene to Early Eocene lignites and associated sediments of Barmer, western India; Palaeobotanist 59 1-32.

Tripathi S K M and Srivastava D 2012 Palynology and palynofacies of the early Palaeogene lignite bearing succession of Vastan, Cambay Basin, western India; Acta Palaeobotanica 52 157-175.

Tripathi S K M, Kumar M and Srivastava D 2009 Palynology of Lower Palaeogene (Thanetian-Ypresian) coastal deposits from the Barmer Basin (Akli Formation, Western Rajasthan, India): Palaeoenvironmental and palaeoclimatic implications; Geologica Acta 7 147-160.

van der Hammen T 1956 A palynological systematic nomenclature; Bol. Geol. Bogota 4 63-101.

van der Hammen T and Wymstra T H 1964 A palynological study of the Tertiary and Upper Cretaceous of British Guiana; Leid. Geol. Meded. 30 183-241.

van Hoeken-Klinkenberg P M J 1966 Maastrichtian, Palaeocene and Eocene pollen and spores from Nigeria; Leid. Geol. Meded. 38 37-48.

Venkatachala B S and Kar R K 1969 Palynology of the Tertiary sediments of Kutch-1-Spores and pollen from Borehole no. 14; Palaeobotanist 17 157-278.

Venkatachala B S and Rawat M S 1973 Palynology of the Tertiary sediments in the Cauvery Basin-2. OligoceneMiocene palynoflora from the subsurface; Palaeobotanist 22 238-263.

Venkatachala B S, Caratini C and Kar R K 1989 PalaeoceneEocene marker pollen from India and tropical Africa; Palaeobotanist 37(1) 1-25.

Wall D 1967 Fossil microplankton in deep-sea cores from the Caribbean Sea; Paleontology 10 95-123.

Zachos J C, Dickens G R and Zeebee R E 2008 An early Cenozoic perspective in green house warming and carboncycle dynamics; Nature 451 279-283. 